\title{
On the road: Clinical trials with stem cell extended to non-hematologic disease
}

\author{
Jinyang Yu, Yanqiu Yu* \\ Department of Pathophysiology, College of Basic Medical Science, China Medical University, Shenyang, China \\ Email: *yqyu@mail.cmu.edu.cn
}

Received 6 November 2012; revised 8 December 2012; accepted 16 December 2012

\begin{abstract}
Increasing evidence in scientific journals declares that stem cell can be used in human medicine for therapeutic purposes. We reviewed the lated literature on clinical trials conducted with stem cells. The main information was offered by

http://www.ClinicalTrials.gov. These clinical trials cover almost all human diseases, from hematologic diseases to non-hematologic diseases including Interventional trials and observational trials. In conclusion, at present, the clinical trials with stem cells have been extending to almost all human diseases. Optimal medicinal effect reported in some non-hematologic diseases is pushing the advance of stem cells therapy.
\end{abstract}

Keywords: Stem Cell; Clinical Trials; Hematologic Disease; Non-Hematologic Disease

\section{INTRODUCTION}

Stem cells are generally defined as cells exhibiting two properties: a capacity for self-renewal and potency for multilineage differentiation [1]. Since the first case on bone marrow transplantation, studies on stem cells therapy have been extending into almost all kinds of human diseases for repairing defected tissue and function. http://www.ClinicalTrials.gov offers up-to-date information for a wide range of diseases and conditions. The studies listed in this database are conducted in 181 countries. We analyzed the information obtained from

http://www.ClinicalTrials.gov with "stem cells" as the searching words. As of June 11, 2012, there were 4061 clinical trials including ongoing, completed and terminated clinical trials worldwide. Base on this database we presented some information on stem cells therapy in the future.

As showed in Figure 1, it is obvious that stem cells are increasingly used in the clinical trials of treating non-hematologic diseases, which makes up the major part.

${ }^{*}$ Corresponding author.
In addition, the promising outcome has been generated on the study of hematologic diseases. It indicates the further clinical applications. Also, there are some stem cell-related trials in the searching results, which are referred as "others" in the Figure 1, this part is considered as the safety and efficacy studies. It mainly includes the harvesting, purifying and identifying process of stem cells, the treatment of complication especially graftversus-host disease after transplantation and so on. They compose a large part of the clinical trials of stem cells as well.

\section{CLINICAL TRIALS ON HEMATOLOGIC DISEASES}

Hematological malignancies are estimated to represent about $8 \%-9 \%$ of all newly diagnosed malignancies every year in the United States, in 2012 according to most recent data [2]. It is also estimated to be responsible for cancer deaths in about 9\% in 2012 in the United States. Stem cells can serve as hematopoietic cells for the improvement of hematological diseases.

So, it's urgent to perform clinical trials of stem cells, focusing on different kinds of hematologic diseases, using different stem cell sources as shown by several examples. From the aspect of diseases, M.D. Anderson Cancer Center [3] sponsored one of the first clinical trials approved by National Institute Health (NIH) on November 1 , 1999. It mainly focused on the stem cell transplantation for leukemia and myelodysplastic syndromes and lasted for nearly ten years, which is still ongoing. St. Jude Children's Research Hospital [4] sponsored clinical trial about stem cell transplantation for sickle cell disease. Fred Hutchinson Cancer Research Center/University of Washington Cancer Consortium [5] sponsored the clinical trial about stem cell transplantation for many different kinds of hematologic diseases. From another side, lots of trials are still ongoing, some of these have already finished and gained the result. M.D. Anderson Cancer Center [6] has completed a clinical trial and got prospective results [7]. The allogenic stem cell transplantation 


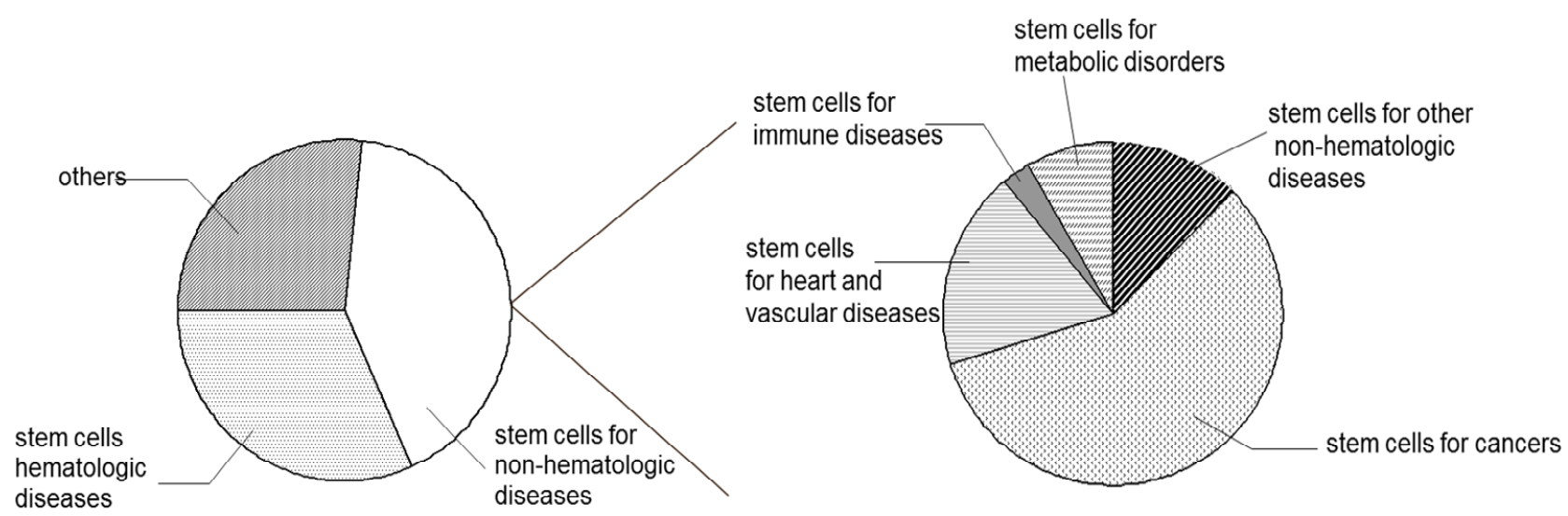

Figure 1. The construction of clinic trials with stem cells therapy and components of non-hematologic diseases in stem cells therapy. The former one is composed of hematologic diseases, non-hematologic diseases and others (trials with stem cells for other diseases). Information from http://www.ClinicalTrials.gov by June 11, 2012.

can cause immunologic rejection, so people develop transplantation with autologous stem cells. Fred Hutchinson Cancer Research Center [8] set the clinical studies about autologous peripheral blood stem cell transplant for the treatment of acute myelogenous leukemia, which was approved on November 1, 1999. Emory University [9], University of Bologna. Autologous Transplantation for Multiple Myeloma [10], Fudan University [11] and an increasing number of people sponsored clinical trials with autologous stem cells.

\section{CLINICAL TRIALS ON NON-HEMATOLOGIC DISEASES}

As the results about stem cells have improved a lot, peonple consider them as a newly-developed cure for some incurable non-hematologic diseases. Referring to the right chart in Figure 1, stem cells therapy about nonhematologic diseases mainly focus on the management of cancers and heart diseases. However, disease like systemic lupus erythematosus lacking effective cure is also the goal of stem cells therapy. The range of diseases is extending and the number is increasing.

\subsection{Heart and Vascular Diseases}

Heart failure has sustained its place as the leading cause of death in the United States over the past two decades and is characterized by the progression of electrical and mechanical dysfunction [12]. There are plenty of clinical trials for the pursue of curing untreatable heart diseases, such as acute myocardial infarction (AMI). National Heart Institute, Mexico [13], Meshalkin Research Institute of Pathology of Circulation [14], Barts \& The London NHS Trust [15], University of Zurich [16] investigated clinical trials with autologous stem cell injection to improve the heart function after acute myocardial infarction. Kyoto Prefectural University of Medicine [17] de- veloped a clinical trial to study the treatment for congestive heart failure, ischemic cardiomyopathy, ventricular dysfunction with autologous cardiac-derived stem cells.

\subsection{Metabolic Disorders}

Metabolic disorders especially diabetes have generated great attention due to the living quality improving. Without effective treatment changing the situation, the studies about stem cells offer a new sight for the treatment. Shanghai Jiao Tong University School of Medicine [18] sponsored a clinical trial on the application of stem cells in treating type1 diabetes. The findings reported were with $67 \%$ of patients remaining noninsulin dependent at the 12-month follow-up and the remarkable increase of C-peptide production suggesting improved $\beta$ cell function [19]. Also, clinical trials on other metabolic disorders emerged. Boston Medical Center [20], Stanford University [21] investigated different clinical trials about stem cell transplant for amyloidosis. Adistem Ltd. [22], institution of Cellonis Biotechnology Co. Ltd. [23], Postgraduate Institute of Medical Education and Research [24] tried different types of stem cells in treating type2 diabetes.

\subsection{Immune Diseases}

The first nonmyeloablative allogenic hematologic stem cell transplantation (AHST) was performed in a single patient with severe refractory systemic lupus erythematosus in Genoa in 1996, with positive outcome [25]. Consequently, clinical trials on systemic lupus erythematosus showed up first on July 5, 2000 [26]. Then, National Cancer Institute (NCI) [27], Charite University, Berlin, Germany [28], Richard Burt, MD [29], National Heart, Lung, and Blood Institute (NHLBI) [30] developed several trials focusing on systemic lupus erythematosus with autologous or allogenic stem cells. In addition, 
St. Jude Children's Research Hospital [31], National Human Genome Research Institute (NHGRI) [32] and some sponsors tried clinical trials of stem cells combined with gene therapy to relieve severe combined immunodeficiency syndrome.

\subsection{Cancers}

In 2007, cancer caused about $13 \%$ of all human deaths worldwide (7.9 million). Rates are rising as more people live to an old age and as mass lifestyle changes occur in the developing world [33]. Cancer cells own the ability of unregulated growth, which leads to the difficulty of treatment. Cancer is usually treated with chemotherapy, radiation therapy and surgery, but the large scale of killing cells makes the situation worse. Stem cell transplantation provides an approach for cell replacement and tissue repairing during the treating process. $\mathrm{H}$. Lee Moffitt Cancer Center and Research Institute [34], Robert H. Lurie Cancer Center [35], Northwestern University [36] have been studying chemotherapy plus stem cell transplantation in treating breast cancer in different trials.

\section{CONCLUSIONS}

As shown above, stem cells therapy has been widely tried in clinical trials. For the reason that bone marrow or hematologic stem cell transplant has been used in clinic for the treatment of leukemia [37], the main focus of stem cell clinical trials has been extended to the application in non-hematologic diseases from hematologic diseases. In addition, the high attack rate and low recovery ratio of non-hematologic diseases urge researchers to develop stem cells therapy as a fresh relief and cure way. The properties of stem cells provide a brilliant view in treating the refractory non-hematologic diseases, e.g. the potency for neuron differentiation makes stem cells relieve the symptoms of Parkinson's syndrome. Besides, both kinds of clinical trials are still ongoing (Table 1) although the ratio of non-hematologic diseases in clinical trials has surpassed that of hematologic diseases.

With the data of stem cell clinical trials, it has a great chance that stem cells therapy can gain a bright future in non-hematologic diseases. However, it is particularly important to investigate the safety and efficacy of stem

Table 1. The examples of ongoing clinical trials with stem cells on different diseases. Information from http://www.clinicaltrials.gov, by June 11, 2012.

\begin{tabular}{|c|c|c|c|}
\hline Rank status & Study & Cells & Disease \\
\hline $\begin{array}{l}\text { 1. Recruiting } \\
\text { participants }\end{array}$ & $\begin{array}{l}\text { Busulfan plus clofarabine followed by allogeneic } \\
\text { hematopoietic stem cell transplantation }\end{array}$ & Hematopoietic stem cell & $\begin{array}{l}\text { Leukemia lymphoma } \\
\text { acute lymphoblastic } \\
\text { leukemia }\end{array}$ \\
\hline $\begin{array}{l}\text { 2. Recruiting } \\
\text { participants }\end{array}$ & $\begin{array}{l}\text { Stem cell transplant in treating patients with acute } \\
\text { myeloid leukemia }\end{array}$ & $\begin{array}{l}\text { Bone marrow hematopoietic stem } \\
\text { cell stem peripheral blood cell }\end{array}$ & Leukemia \\
\hline $\begin{array}{l}\text { 3. Not yet open for } \\
\text { participant } \\
\text { recruitment }\end{array}$ & $\begin{array}{l}\text { Safety study of mesenchymal precursor cells in type } 2 \\
\text { diabetes }\end{array}$ & Mesenchymal precursor cells & Type 2 diabetes \\
\hline $\begin{array}{l}\text { 4. Not yet open for } \\
\text { participant } \\
\text { recruitment }\end{array}$ & $\begin{array}{l}\text { Safety and efficacy study of umbilical mesenchymal stem } \\
\text { cells for liver cirrhosis() (LC) }\end{array}$ & Umbilical mesenchymal stem cells & Liver cirrhosis \\
\hline 5. Completed & $\begin{array}{l}\text { Stem cell therapy to improve myocardial function in } \\
\text { patients with acute myocardial infarction }\end{array}$ & Bone marrow-derived stem cells & Myocardial infarction \\
\hline $\begin{array}{l}\text { 6. Recruiting } \\
\text { participants }\end{array}$ & $\begin{array}{l}\text { To study the safety and efficacy of autologous bone } \\
\text { marrow stem cells in patients with spinal cord injury }\end{array}$ & Bone marrow stem cells & Spinal cord injury \\
\hline 7. Terminated & $\begin{array}{l}\text { Hematopoietic stem cell therapy for patients with } \\
\text { multiple sclerosis }\end{array}$ & Hematopoietic stem cell & Multiple sclerosis \\
\hline $\begin{array}{l}\text { 8. Recruiting } \\
\text { participants }\end{array}$ & $\begin{array}{l}\text { Safety/feasibility of autologous mononuclear bone } \\
\text { marrow cells in stroke patients }\end{array}$ & Mononuclear bone marrow cells & Ischemic stroke \\
\hline $\begin{array}{l}\text { 9. Recruiting } \\
\text { participants }\end{array}$ & $\begin{array}{l}\text { Nonmyeloablative allo stem cell transplant for severe } \\
\text { autoimmune disease }\end{array}$ & Peripheral blood stem cell & $\begin{array}{l}\text { Systemic lupus } \\
\text { erythematosus }\end{array}$ \\
\hline $\begin{array}{l}\text { 10. Recruting } \\
\text { participants }\end{array}$ & $\begin{array}{l}\text { Autologous peripheral blood stem cell transplant for germ } \\
\text { cell tumors }\end{array}$ & Peripheral blood stem cell & $\begin{array}{l}\text { Childhood germ cell } \\
\text { tumor ovarian cancer } \\
\text { teratoma }\end{array}$ \\
\hline
\end{tabular}


cells therapy. It is critical to deal with plenty of problems existing in the stem cells transplantation. For example, the difficulty in harvesting, purifying and identifying stem cells; the application way, indications and evaluation on therapeutic effects in clinic are still exploring. Although stem cells therapy has significant potential in treating non-hematologic diseases. The more and more researches are the stem cells reach road.

\section{REFERENCES}

[1] Reya, T., Morrison, S.J., Clarke, M.F. and Weissman, I.L. (2001) Stem cells, cancer, and cancer stem cells. Nature, 414, 105-111. doi:10.1038/35102167

[2] Cancer statistics (Epub ahead of print) (2012).

[3] M.D. Anderson Cancer Center (2010) Decitabine and peripheral stem cell transplantation in treating patients who have relapsed following bone marrow transplantation for leukemia, myelodysplastic syndrome, or chronic myelogenous leukemia.

http://clinicaltrials.gov/ct2/show/NCT00002832

[4] St. Jude Children's Research Hospital (2009) Haploidentical stem cell transplant for patients with sickle cell disease and prior stroke or abnormal transcranial ultrasound. http://clinicaltrials.gov/ct2/show/NCT00152113

[5] Fred Hutchinson Cancer Research Center/University of Washington Cancer Consortium (2012) Donor peripheral blood stem cell transplant in treating patients with hematologic malignancies.

http://clinicaltrials.gov/ct2/show/NCT01028716

[6] M.D. Anderson Cancer Center (2011) Non-myeloablative allogeneic stem cell transplantation.

http://clinicaltrials.gov/ct2/show/NCT00525876

[7] Efebera, Y.A., Qureshi, S.R. and Khouri, I.F. (2010) Reduced-intensity allogeneic hematopoietic stem cell transplantation for relapsed multiple myeloma. Biology of Blood and Marrow Transplantation, 16, 1122-1129. doi:10.1016/j.bbmt.2010.02.015

[8] Fred Hutchinson Cancer Research Center (2011) Busulfan and etoposide followed by peripheral blood stem cell transplant and low-dose aldesleukin in treating patients with acute myeloid leukemia.

http://clinicaltrials.gov/ct2/show/NCT00003875

[9] Emory University (2011) Combination high dose melphalan and autologous peripheral blood stem cell (PBSC) transplant with bortezomib for multiple myeloma: A dose and schedule finding study. http://clinicaltrials.gov/ct2/show/NCT00793650

[10] University of Bologna (2006) Autologous transplantation for multiple myeloma. http://clinicaltrials.gov/ct2/show/NCT00378222

[11] Fudan University (2012) IGEV followed by autologous transplantation for refractory or relapsed hodgkin lymphoma. http://clinicaltrials.gov/ct2/show/NCT01333605

[12] American Heart Association (2008) http://www.americanheart.org

[13] National Heart Institute, Mexico (2008) Intracoronary autologous stem cell transplantation in ST elevation myocardial infarction: Tracia study.

http://clinicaltrials.gov/ct2/show/NCT00725738

[14] Meshalkin Research Institute of Pathology of Circulation (2012) "Estimation study" for endocardial mesenchymal stem cells implantation in patients after acute myocardial infarction.

http://clinicaltrials.gov/ct2/show/NCT01394432

[15] Barts \& The London NHS Trust (2011) Bone marrow derived adult stem cells for acute anterior myocardial infarction (REGEN-AMI).

http://clinicaltrials.gov/ct2/show/NCT00765453

[16] University of Zurich (2008) Swiss multicenter intracoronary stem cells study in acute myocardial infarction (SWISS-AMI).

http://clinicaltrials.gov/ct2/show/NCT00355186

[17] Kyoto Prefectural University of Medicine (2011) Autologous human cardiac-derived stem cell to treat ischemic cardiomyopathy (ALCADIA). http://clinicaltrials.gov/ct2/show/NCT00981006

[18] Shanghai Jiao Tong University, School of Medicine (2012) Autologous hematopoietic stem cell transplantation for early onset type 1 diabetes. http://clinicaltrials.gov/ct2/show/NCT00807651

[19] Zhang., X.F., Ye, L. and Hu, J. (2012) Acute response of peripheral blood cell to autologous hematopoietic stem cell transplantation in type 1diabetic patient. PLOS One, 7, e31887. doi:10.1371/journal.pone.0031887

[20] Boston Medical Center (2012) Bortezomib and dexamethasone followed by high-dose melphalan and stem cell transplantation for primary (AL) amyloidosis. http://clinicaltrials.gov/ct2/show/NCT01083316

[21] Stanford University (2010) Autologous stem cell rescue for primary amyloidosis.

http://clinicaltrials.gov/ct2/show/NCT00186407

[22] Adistem Ltd. (2008) Safety and efficacy of autologous adipose-derived stem cell transplantation in type 2 diabetics. http://clinicaltrials.gov/ct2/show/NCT00703612

[23] Cellonis Biotechnology Co. Ltd. (2010) Stem cell therapy for type 2 diabetes mellitus.

http://clinicaltrials.gov/ct2/show/NCT01142050

[24] Postgraduate Institute of Medical Education and Research (2008) Efficacy of autologous bone marrow derived stem cell transplantation in patients with type 2 diabetes mellitus (SCT). http://clinicaltrials.gov/ct2/show/NCT00644241

[25] Marmont, A.M., van Lint, M.T., Gualandi, F. and Bacigalupo, A. (1997) Autologous marrow mstem cell transplantation for systemic lupus erythematosus of long duration. Lupus, 6, 545-548. doi:10.1177/096120339700600613

[26] Fairview University Medical Center (2005) Autologous peripheral blood stem cell transplantation in patients with life threatening autoimmune diseases. http://clinicaltrials.gov/ct2/show/NCT00006055

[27] National Cancer Institute (NCI) (2012) Lymphocyte depletion and stem cell transplantation to treat severe systemic lupus erythematosus. 
http://clinicaltrials.gov/ct2/show/NCT00076752

[28] Charite University (2011) Autologous stem cell transplantation for refractory systemic lupus erythematosus (ASSIST).

http://clinicaltrials.gov/ct2/show/NCT00750971

[29] Burt, R. (2012) Allogeneic stem cell transplantation in systemic lupus erythematosus. http://clinicaltrials.gov/ct2/show/NCT00278590

[30] National Heart, Lung, and Blood Institute (NHLBI) (2009) Allogeneic blood stem cell transplantation for patients with life-threatening systemic lupus erythematosus. http://clinicaltrials.gov/ct2/show/NCT00325741

[31] St. Jude Children's Research Hospital (2009) Transplantation of hematopoietic cells in children with severe combined immunodeficiency syndrome. http://clinicaltrials.gov/ct2/show/NCT00152100

[32] National Human Genome Research Institute (NHGRI) (2012) Gene transfer therapy for severe combined immunodeficieny disease (SCID) due to adenosine deami- nase (ADA) deficiency. http://clinicaltrials.gov/show/NCT00018018

[33] Jemal, A., Bray, F., Center, M.M., Ferlay, J., Ward, E. and Forman, D. (2011) Global cancer statistics. A Cancer Journal for Clinicians, 61, 69-90.

[34] H. Lee (2009) Combination chemotherapy followed by peripheral stem cell transplantation in treating women with metastatic breast cancer. http://clinicaltrials.gov/ct2/show/NCT00006032

[35] Robert H. and Lurie Cancer Center (2009) Combination chemotherapy and peripheral stem cell transplantation in treating women with metastatic breast cancer. http://clinicaltrials.gov/ct2/show/NCT00004906

[36] Northwestern University (2011) Chemotherapy, filgrastim, and stem cell transplantation with radiation therapy in treating patients with stage III or stage IV breast cancer. http://clinicaltrials.gov/show/NCT00004172

[37] www.medicinenet.com 